\title{
Equity, Access, and Diversity through Short-term Study Abroad in Online Education Programming
}

\section{Clothey, Rebecca A.}

Drexel University School of Education, United States

\begin{abstract}
This paper describes the challenges of creating quality international educational opportunities for non-traditional adult learners who are studying online and have families and full-time jobs. The paper discusses the potential for success of an education model for study abroad designed specifically to address the needs of this student population. It concludes that although the model attracted some students among the target population who may not otherwise have gone abroad, more work needs to be done to create inclusive study abroad models.
\end{abstract}

Keywords: study abroad; online education; non-traditional students. 


\section{Introduction}

International education has been praised as a way to facilitate cross-cultural awareness and global citizenship. However - although the US post-secondary student body has never been so diverse in terms of age, race, ethnicity, and gender - males and ethnic minorities tend to be underrepresented in the US student population studying abroad (Obst et al., 2007). This paper describes the challenges of creating quality international educational opportunities for non-traditional ${ }^{1}$ adult learners who have families and full-time jobs. The paper discusses the potential for success of an education model for study abroad designed specifically to address the needs of this student population.

\section{Higher Education, Non-traditional Students, and Study Abroad}

The massification of higher education in the United States has led to a more diversified student population, with the proportion of White college students declining, while racial and ethnic minorities have increased (Snyder, 2011). In addition, as of 2009 approximately 42 percent of college students were over the age of 25 (Clothey et al., 2012). Massification of higher education is due in part to new pathways for access, including distance learning. Indeed, online enrollments in the United States are growing faster than the overall higher education student population, with almost $30 \%$ of students taking one online course (Allen and Seamen, 2017). The flexibility of online courses appeals to students with constraints such as family or work responsibilities, or because of geographic limitations (Clothey, 2016). However, the online student profile across the United States tends to be mostly women, with almost half above age 26 .

Despite the diversity in higher education generally, research shows that certain populations continue to be underrepresented in study abroad, including males, minorities, and nontraditional aged students (Stroud, 2010). Perceived barriers to studying abroad among these populations include academic, personal and financial concerns (Forum, 2009). Certain majors are also underrepresented in study abroad. For example, although business and education are among the largest number of degrees awarded in the U.S., only $4.1 \%$ of education majors studied abroad in the 2009/10 academic year, compared with $20 \%$ of business majors (IIE, 2011). Such a low percentage of education majors going abroad is troubling given that that population is most likely to be shaping the future by working with

\footnotetext{
${ }^{1}$ According to NCES (n.d.), non-traditional students are characterized as being over the age of 24. "Age acts as a surrogate variable that captures a large, heterogeneous population of adult students who often have family and work responsibilities as well as other life circumstances that can interfere with successful completion of educational objectives." (NCES, n.d., p. 1).
} 
children. As a key to broadening the mind, study abroad programming should be an essential component of an education degree. Master's degree students are even less likely to study abroad than those enrolled in Bachelor's degree programs (Stroud, 2010).

\section{Barriers for Non-traditional Online Students to Study Abroad}

The study abroad programs referred to in this study were designed to enhance an online Master's degree program in international education based at a private comprehensive university located in the northeast of the United States. Although the program is by nature international, with a student body and instructors residing worldwide, designing a study abroad program that would be appropriate for the sparsely located and non-traditional student population was a challenge. Most students enrolled in the program fit the profile of typical online students and also fall within one of the underrepresented groups for study abroad. They are full-time working professionals taking online courses because they do not have time to attend face to face courses several times a week. The program's students range in age from 22 to 52, and many of them are also spouses, parents, and even grandparents, requiring additional demands on their time (Clothey, 2016).

In an internal analysis, barriers that students identified would prevent them from studying abroad included: getting enough time off from work, having to make babysitting arrangements for children while abroad, the cost of travel, the cost of not working while traveling, and timing. Most students in the program work as full-time as teachers, and therefore are more likely to consider study abroad options offered during the summer (Clothey, 2016). According to Stroud (2010), financial concerns are not the top limitation for most students studying abroad, due to the 2007 Simon Act, which allows students to use financial aid for study abroad if it is required for course credit.

However, our internal analysis reflected the opposite. For these students, time and money mattered a lot, because even with financial aid to support a student while abroad, the nontraditional student may still face expenses at home that need to be attended to. As one respondent stated: "Not working and having to pay all of the usual bills while abroad is not easy for adult working students" (Brack, as cited in Clothey, 2016, p. 27).

\section{Incorporating Short-Term Study Abroad into an Online Model}

Short-term study abroad that offers programs for shorter lengths of time than a semester or academic year has contributed to a growth in study abroad enrollment (IIE, 2008). Indeed, more than half (approximately 56\%) of U.S. students enroll in these, compared with $39 \%$ of students studying abroad for an entire semester (IIE, 2011). However, some study abroad 
advocates claim that longer programs are better, and provide deeper cultural immersion opportunities (IIE White Paper 2007). In 2009 the Forum on Education Abroad produced a list of nine standards of good practice for short-term education programs to respond to this concern. The standards emphasize creating short-term programs with well-defined academic objectives (Forum, 2009).

Thus, in line with the Forum's suggestions and student needs, a model for a short-term study abroad program of no longer than 2 weeks in duration was developed that would be integrated with a 3 -credit online course. The rationale was that a short-term stand-alone study abroad program would have less academic value for fostering student learning and development (Forum, Standard 2) than one which was integrated into a full academic-term experience. In addition, it was believed that integrating a mandatory short-term study abroad component into a full 3-credit course would have potential to attract more students. Participants could take the course as part of the credits needed toward their graduation, and they would also be eligible for financial aid under the Simon Act, which allows students to use financial aid for study abroad if it is required for course credit (Clothey, 2016).

In the short-term study abroad model adopted by the program, students participated in class online during the first four weeks of the term, in which they learned about the history and key issues of the target country. This academic foundation prepared students for meeting in person in country, for 8-10 days of on-site lectures, meetings, and visits to key sites relevant to the course topic. When students returned from the trip they had another two weeks of class online, during which time they reflected on the experience and completed final projects related to the course theme. The courses were offered in consecutive years during the summer term, in order to include as many students as possible.

\section{Potential of Model Success}

Wheeler (2000) notes that although study abroad enrollments are increasing, stays abroad are getting shorter. In the past, short-term study abroad programs were considered undemanding and not valuable, but recent studies have shown that students who participated in short-term study abroad programs gained the same personal and intellectual growth as those who enrolled in traditional long-term study abroad programs of a semester or more. For students who wish to have the experience of studying abroad and getting a taste of another culture but perhaps do not have the time, money, or resources to complete a traditional semester or year abroad, short-term programs may be ideal.

Evaluations for the study abroad programs described here similarly indicated that the online students also gained a great deal from their short-term stay abroad. Embedding the program within the context of a larger 3-credit course ensured that students were able to maximize 
their short time abroad and gain a meaningful experience with relevant preparation and knowledge. According to participant feedback, hands on learning about the subjects they were studying in their coursework, as well as the opportunity for face-to-face interaction greatly enhanced the learning experience (Clothey, 2016). Most significantly, the shortterm format of the program attracted some students who would not study abroad in a more traditional academic format.

Nevertheless, an examination of the programs' student demographics indicate that the population was not as diverse as had been hoped. The proportion of minority students who participated in any of the programs was low; however, the online program's minority population is also proportionately low. Thus, the minority population on the trips was representative.

Interestingly, although minority students tend to be an underrepresented group in study abroad, all of the minority students who participated in either trip described in this paper had been abroad more than once prior to the integrated online short-term study abroad. In contrast, there were white students on both trips who had never before traveled abroad. Three had never left the United States, and one of these also had very limited experience outside of her home state prior to her trip abroad. More research is needed to ascertain to what extent the integrated online study abroad model may have encouraged these students to participate.

Additionally, although almost a fourth of the online program's students are parents, only two students with children participated in one of the integrated online study abroad programs discussed in this paper. Given that childcare was identified as a constraint against studying abroad among this online student population, this was not a surprise. Yet, it may be significant that any parents participated at all (Clothey, 2016).

Though this case discusses the experience of integrated online study abroad within only one university's Master's degree program, it does illuminate the fact that as the US student population continues to become more diverse, education models must also change and respond to adapt to the changing student needs. If study abroad programs especially designed for target populations are carefully considered, planned, and implemented, study abroad may become a more viable option even for students who face great obstacles in participating.

\section{References}

Allen, I.E. and Seamen, J. (2012). Going the Distance: Online Education in the United States, 2011. Babson Park, MA: Babson Survey Research Group and Quahog Research Group, LLC. 
Carroll, A. V. (1996). Increasing the participation of historically underrepresented students in study abroad programs: An assessment of interest and perception of barriers. Unpublished master's thesis, Colorado State University, Fort Collins, Colorado

Clothey, R. (2016). Increasing diversity in international education: Programming for nontraditional students through an alternative curriculum model. International Journal of Curriculum and Instruction 8(1): 22-35.

Clothey, R., Austin-Li, S., \& Weidman, J.C. (2012). Post-Secondary education and technology: A global perspective on opportunities and obstacles to development. New York: PalgraveMacMillan.

Forum on Education Abroad (2009). Standards of Good Practice. Available online at http://www.forumea.org.

Institute of International Education (IIE) (2007). Opening Minds to the World: Annual Report. Available online at http://www.iie.org.

Institute of International Education (IIE) (2011). Open Doors Fast Facts 2011. Available online at: http://www.iie.org.

Obst, D., Bhandari, R., and Witherell, S. (2007). Current Trends in U.S. Study Abroad \& The Impact of Strategic Diversity Impacts: White Paper. New York: Institute of International Education.

Snyder, T. D. (2011). Mini-digest of education statistics, 2010. U.S. Department of Education National Center for Education Statistics (NCES). Report no. NCES 2011016. Washington, DC: NCES. Available online at: http://nces.ed.gov.

Stearns, P. (2009). Educating Global Citizens in Colleges and Universities: Challenges and Opportunities. New York: Routledge.

Stroud, A. (2010). Who Plans (Not) to Study Abroad? An Examination of U.S. Student Intent. Journal of Studies in International Education, 14(5): 491-507.

Wheeler, D. (2000). "More Students Study Abroad, but Their Stays Are Shorter." Chronicle of Higher Education, (47): 12. 